\title{
An Overview of COVID-19 Medicines in Current Guidelines
}

\section{Güncel Kılavuzlardaki COViD-19 illaçlarına Bir Bakış}

(D) Mustafa GÖKÇE1, iD Eray Metin GÜLER2

${ }^{1}$ Bezmialem Vakıf University Faculty of Pharmacy, Department of Pharmacology, İstanbul, Turkey

${ }^{2}$ Bezmialem Vakıf University Faculty of Medicine, Department of Medical Biochemistry, İstanbul, Turkey

\begin{abstract}
An acute respiratory disease caused by a new coronavirus (Severe acute respirotary syndrome-coronavirüs-2, previously known as 2019-nCoV), coronavirus disease 2019 (COVID-19), appeared in December 2019 and then has spread rapidly throughout the world starting from China, Japan and South Korea. As of January 30, 2020, the World Health Organization has officially declared the COVID-19 outbreak. Considering the clinical symptoms of COVID-19, it has many symptoms such as high fever, cough, and fatigue. It is reported that this disease is very severe and causes serious consequences such as cytokine storm and acute respiratory distress syndrome in the elderly and those with chronic diseases. Currently, scientists are trying to find a specific antiviral treatment strategy. Various medications such as hydroxychloroquine, lopinavir/ ritonavir, ribavirin, remdesivir and favipiravir are currently being applied in clinical trials to test their efficacy and safety worldwide in COVID-19 treatment, and some promising results have been achieved so far. In this review, agents with potential efficacy against COVID-19 are presented in summary.
\end{abstract}

Keywords: COVID-19, antivirals, treatment, SARS-CoV-2

\section{ÖZ}

Yeni bir koronavirüsün (daha önce 2019-nCoV olarak bilinen Şiddetli akut solunum enfeksiyonu-koronavirüs-2) neden olduğu akut solunum yolu hastalığı, koronavirüs hastalığı 2019 (COVİD-19) Aralık 2019'da ortaya çıkmış ve daha sonra Çin, Japonya ve Güney Koreden başlayarak Dünya genelinde hızlı bir yayılım göstermiştir. 30 Ocak 2020 itibariyle de Dünya Sağlık Örgütü COVİD-19 salgınını resmi olarak ilan etmiştir. COVİD-19'un klinik semptomlarına bakıldığında yüksek ateş, öksürük, yorgunluk gibi birçok semptomu vardır. Yaşlılarda ve kronik hastalıkları olanlarda bu hastalığın çok ağır geçtiği ve sitokin firtınası ile akut solunum sıkıntısı sendromu (ARDS) gibi ciddi sonuçlara neden olduğu bildirilmektedir. Şu anda bilim insanları tarafindan spesifik antiviral tedavi stratejisi bulunmaya çalışılmaktadır. Hidroksiklorokin, lopinavir/ritonavir, ribavirin, remdesivir ve favipiravir gibi çeşitli ilaçlar şu anda Dünya çapında COVID-19 tedavisinde etkinliklerini ve güvenliklerini test etmek için klinik çalışmalarda uygulanmaktadır ve şimdiye kadar bazı umut verici sonuçlar elde edilmiştir. Bu derlemede, COVID-19'a karşı potansiyel etkinliği olan ajanlar özet halinde sunulmaktadır.

Anahtar Sözcükler: COVID-19, antiviraller, tedavi, SARS-CoV-2

\section{Introduction}

The Severe acute respirotary syndrome-coronavirus- 2 virus (formerly 2019-nCoV) appeared in Wuhan, Hubei province of China in December 2019, and then spread very rapidly across the world, starting from China, Japan and South Korea. To date, more than 3 million cases and more than 200 thousand deaths have been reported worldwide (1). The first COVID-19 case was confirmed in Turkey on March 10, 2020 and a total of 107,773 cases were approved as of April $25^{\text {th }} 2020$, and it was reported that a total of 2,706 patients died (2). Considering the lack of effective antiviral therapy against COVID-19, current treatments 
are predominantly for symptoms (3). That is why, scientists have recently intensified their work rapidly on drug therapy for COVID-19 treatment. We can use some treatment strategies against coronaviruses based on the experience of struggling in SARS-CoV and Middle East Respiratory Syndrome corona virus
(MERS-CoV) outbreaks (4). Some agents have been quickly tested in clinical trials and have been reported to show activity against COVID-19 (5). The summary of current adult and pediatric patient medication guideline published by the Republic of Turkey Ministry of Health dated April 14, 2020 is shown in

Table 1. Current guideline for adult and child patient drug treatment

Name of drug

Dosage

Administration way

Time

Treatment recommendations for asymptomatic definite COVID-19 cases to be monitored as outpatient and for uncomplicated patients or patients with mild pneumonia-possible COVID-19

\begin{tabular}{l|l|l} 
Hydroxychloroquine & $2 \times 200 \mathrm{mg}$ & Oral
\end{tabular}

Recommendations for COVID-19 Patients with indication for hospitalization

Treatment in uncomplicated possible/definitely diagnosed COVID-19 Cases

\begin{tabular}{l|l|l|l|}
\hline Hydroxychloroquine & $2 \times 200 \mathrm{mg}$ & Oral & 5 days \\
\hline -/+ Azithromycin & $1^{\text {st }}$ day $500 \mathrm{mg}+250 \mathrm{mg} \times 4$ days & Oral & 5 days \\
\hline Treatment in possible/definitely diagnosed & COVID -19 cases with severe pneumonia & \\
\hline Hydroxychloroquine & $2 \times 400 \mathrm{mg}$ loading dose $+2 \times 200 \mathrm{mg}$ & Oral & 5 days \\
\hline$-/+$ Favipiravir & $2 \times 1,600 \mathrm{mg}$ loading dose $+2 \times 600 \mathrm{mg}$ & Oral & 5 days \\
\hline maintenance dose & Oral & 5 days
\end{tabular}

Treatment in patients whose pneumonia findings have progressed while receiving hydroxychloroquine treatment

Favipiravir

(Hydroxychloroquine treatment should be completed within 10 days and stopped)
$2 \times 1,600 \mathrm{mg}$ loading dose $+2 \times 600 \mathrm{mg}$

maintenance dose
Oral

5 days

Treatment in pregnants with the definite diagnosis of COVID-19

Hydroxychloroquine
-/+ Lopinavir $200 \mathrm{mg} /$
Dosages and administ
Hydroxychloroquine

-/+ Azithromycin

-/+ Lopinavir 200 mg/ Ritonavir 50 mg
$2 \times 200 \mathrm{mg}$

$200 \mathrm{mg} / 50 \mathrm{mg}$ twice a day
Oral

Oral 10-14 days $6.5 \mathrm{mg} / \mathrm{kg} /$ dose of Hydroxychloroquine for twice on the first day; maximum dose on the first day: $400 \mathrm{mg} /$ dose; on the $2^{\text {nd }}-5^{\text {th }}$ days, $3.25 \mathrm{mg} / \mathrm{kg} /$ dose of Hydroxychloroquine for twice a day: maximum dose $200 \mathrm{mg} /$ dose 1-5 month children $10 \mathrm{mg} / \mathrm{kg} /$ dose (max dose $500 \mathrm{mg} /$ dose)

$>6$ month children and adolescents $10 \mathrm{mg} /$ $\mathrm{kg}$ single dose on the first day (max dose 500 $\mathrm{mg} /$ dose), Then, continuing with $5 \mathrm{mg} / \mathrm{kg}$ single dose a day for 2-5 days (max dose 250 $\mathrm{mg} /$ dose) totally 5 days

Between 14 days-6 months: Lopinavir 16 $\mathrm{mg} / \mathrm{kg}$ PO BID

Between 6 month-old-18 year-old: 15-25 kg: $200 \mathrm{mg}-50 \mathrm{mg}$ PO BID

26-35 kg: $300 \mathrm{mg}-75 \mathrm{mg}$ PO BID

>35 kg: 400 mg-100 mg PO BID
Oral

5 days

Oral

5 days

Oral

10-14 days 
Table $1(6,7)$. In the most current version of the guideline, the use of antimicrobials such as hydroxychloroquine lopinavir/ ritonavir, azithromycin and favipiravir is recommended for the treatment of COVID-19 (Table 2).

Hydroxychloroquine is an antimalarial widely used in malaria, which was discovered to be a potential broad-spectrum antiviral in $2006(8,9)$. Although the mechanism of action of hydroxychloroquine is not fully understood, it appears to block viral entry into cells by inhibiting the glycosylation of host receptors, proteolytic processing and endosomal acidification. This drug has also been shown to suppress cytokine production, such as interleukin (IL)- 6 and tumor necrosis factor- $\alpha$, and has immunomodulatory effects in host cells through the inhibition of lysosomal activity and autophagy $(10,11)$. Chloroquine has the ability to inhibit replication cycles against human immunodeficiency virus (HIV) and other inflammation-related viruses (12).

Hydroxychloroquine has blocked SARS-CoV-2 infection at a low micromolar concentration with a semi-maximum effective concentration $\left(\mathrm{EC}_{50}\right)$ of $1.13 \mu \mathrm{M}$ and a semi-cytotoxic concentration $\left(\mathrm{CC}_{50}\right)$ greater than $100 \mu \mathrm{M}$ (13). Currently, there are some randomized clinical trials that examine their role in COVID-19 therapy (14). Chloroquine is known to inhibit $\mathrm{pH}$ dependent steps of replication of various viruses (11). Hydroxychloroquine studies are planned for post-exposure prophylaxis after chloroquine prophylaxis (NCT04303507) and high-risk exposures (NCT04308668) in healthcare professionals (15). Although the antiviral properties of chloroquine treat people with the disease, it should be remembered that this will change depending on the disease, chloroquine concentration and duration of treatment (16). Chloroquine is still the first drug that comes to mind because it leads to rapid fever reduction and an immediate improvement in lung computed tomography findings, and at least 10 clinical studies are currently being performed (17).

Scientists have used protease inhibitors of lopinavir and ritonavir along with other drugs to treat HIV-1-infected adults and children over the age of 14 years (18) and HIV-infected people (19). Chu et al. (20) have confirmed in in vitro and clinical

Table 2. Potential antivirals used in the treatment process of COVID-19

\begin{tabular}{|c|c|c|c|c|}
\hline Name of Drug & General definition & Mechanism of action & Targeted diseases & Reference \\
\hline $\begin{array}{l}\text { Lopinavir/ } \\
\text { ritonavir }\end{array}$ & Protease inhibitor & $\begin{array}{l}\text { Inhibition of HIV-1 protease for protein cleavage } \\
\text { leading to non-infectious, immature viral particles }\end{array}$ & HIV/AIDS, SARS, MERS & $(19-21)$ \\
\hline Chloroquine & 9-aminoquinoline & $\begin{array}{l}\text { Increased endosomal pH, immunomodulator, } \\
\text { autophagy inhibitors }\end{array}$ & $\begin{array}{l}\text { Malaria, autoimmune } \\
\text { diseases }\end{array}$ & $(11,13,14,41)$ \\
\hline Nafamostat & $\begin{array}{l}\text { Synthetic serine protease } \\
\text { inhibitor }\end{array}$ & $\begin{array}{l}\text { It prevents membrane fusion by reducing } \\
\text { cathepsin B release; anticoagulant activities }\end{array}$ & Influenza, MERS, Ebola & $(45,46)$ \\
\hline $\begin{array}{l}\text { Penciclovir/ } \\
\text { acyclovir }\end{array}$ & Nucleoside analog & $\begin{array}{l}\text { A synthetic acyclic guanine derivative resulting in } \\
\text { chain termination }\end{array}$ & HSV, VZV & (51) \\
\hline Ganciclovir & Nucleoside analog & $\begin{array}{l}\text { Powerful inhibitor of the Herpesvirus family, } \\
\text { including cytomegalovirus }\end{array}$ & $\begin{array}{l}\text { AIDS-related } \\
\text { cytomegalovirus } \\
\text { infections }\end{array}$ & $(52)$ \\
\hline $\begin{array}{l}\text { Favipiravir } \\
\text { (T-705) }\end{array}$ & $\begin{array}{l}\text { Nucleoside analog: } \\
\text { Viral RNA } \\
\text { Polimerase inhibitor }\end{array}$ & $\begin{array}{l}\text { Influencing viral genetic replication to prevent } \\
\text { replication without affecting host cellular RNA or } \\
\text { DNA synthesis }\end{array}$ & $\begin{array}{l}\text { Ebola, Influenza, } \\
\mathrm{A}(\mathrm{H} 1 \mathrm{~N} 1)\end{array}$ & $(53-55)$ \\
\hline
\end{tabular}


studies that lopinavir/ritonavir has anti-SARS-CoV activity and Arabi et al. (21) have confirmed that they have anti-MERS-CoV activity. They also have demonstrated that they can cure patients.

Early reports of lopinavir/ritonavir for the treatment of COVID-19 are mostly case reports and small-scale retrospective, non-randomized cohort studies, which makes it difficult to detect the direct treatment effect of lopinavir/ritonavir. More recently, Cao et al. (22) have reported open-label randomized clinical trial results comparing the efficacy of lopinavir/ritonavir with standard care in 199 patients with COVID-19. A study conducted in South Korea reported that the viral load of a COVID-19 positive patient decreased with lopinavir/ritonavir treatment (23).

Favipiravir is currently one of the drugs that have undergone clinical trials for the treatment of COVID-19. Favipiravir is a new RNA-dependent RNA polymerase inhibitor. Favipiravir is converted into an active phosphoribosyl form (favipiravirRTP) in cells and is recognized by the viral RNA polymerase as a substrate, thereby inhibits RNA polymerase activity (24). Therefore, favipiravir is thought to have a potential antiviral effect on SARS-CoV-2, which is an RNA virus. There are a limited number of clinical trials that support the use of favipiravir for COVID-19. In a prospective, randomized, multicenter study, favipiravir $(n=120)$ was compared with Arbidol $(n=120)$ for the treatment of moderate and severe COVID-19 infections. On the $7^{\text {th }}$ day, clinical improvement differences were observed in patients with moderate infection (71.4\% favipiravir and 55.9\% arbidol, $\mathrm{p}=0.019)$. No significant difference was observed in the severe or severe and moderate (combined) arms (25). In another study conducted in China, considering the first results of a total of 80 patients (including the experimental group and the control group), favipiravir was shown to have a stronger antiviral effect than lopinavir/ritonavirin (26).

Azithromycin is an antibiotic from the macrolide group with a wide range of uses, especially for the treatment of grampositive cocci. Azithromycin has been shown to be active in vitro against Zika and Ebola viruses and to prevent severe respiratory infections when administered to patients who have had a viral infection (27-29). Another study reported that the combination of azithromycin-hydroxychloroquine $(6 / 6,100 \%)$ in 6 COVID-19 patients resulted in numerically superior viral clearance compared to hydroxychloroquine monotherapy $(8 / 14$, 57\%) (30).

In addition to the medicines in the above guidelines, a few more medicines attract attention. Of these, remdesivir, which was developed for Ebola, is an antiviral drug with a nucleoside analog and broad-spectrum anti-RNA (31) and shows broadspectrum antiviral activity against several RNA viruses. Animal experiments (32) have shown that remdesivir can effectively reduce viral load in lung tissue of MERS-CoV-2-infected mice, improve lung function, and alleviate pathological damage in lung tissue. Based on data collected in the in vitro mouse cell culture model, remdesivir has been found to affect NSP12 polymerase in coronaviruses (23). Wang et al. (13) found that remdesivir strongly prevents SARS-CoV-2 infection at low micromolar concentrations and has a high selectivity index. Holshue et al. (31) reported that remdesivir gave promising results in the treatment of a patient with COVID-19 in the USA. The combination of remdesivir and chloroquine has been proven to effectively inhibit the recently occurring SARS-CoV-2 as in vitro. Currently, randomized, placebo-controlled, double-blind phase III studies are being conducted on 761 patients in many hospitals in Wuhan, the first place of outbreak. The results of the trials are expected to be announced in the next few weeks (33). An in vitro activity of oseltamivir, another neuraminidase inhibitor, which is normally approved for influenza treatment, has not been documented against SARS-CoV-2. In China, the COVID-19 outbreak initially occurred during the peak influenza season, so a large number of patients underwent empirical oseltamivir therapy, not as a therapeutic intervention, until SARS-CoV-2 was discovered (34). In current guidelines, it is added to the treatment in viral pneumonia seen with COVID-19 (35). Ribavirin is also one of the new drugs added to the guidelines. It is a broad spectrum nucleoside analogue with antiviral effects. One study compared 111 patients with severe acute respiratory syndrome (SARS) treated with ribavirin and 41 SARS patients treated in combination with lopinavir/ritonavir and ribavirin; Acute respiratory distress syndrome (ARDS) and mortality risk were found to be lower in patients treated with combined therapy (20). However, ribavirin was found to have limited in vitro activity against SARS-CoV and was shown to require high concentrations to inhibit viral replication, which led to high dose and combination therapy (36). It is thought to have limited use for COVID-19 treatment due to its efficacy data and toxicity without ribavirin for other $\mathrm{nCoV}$ types (5). These drugs require more clinical evidence before they are recommended. Other drugs recommended for treatment are arbidol (an antiviral drug available in Russia and China), intravenous immunoglobulin, interferons, and plasma of patients recovered from COVID-19 (37-39). Among the candidate drugs to treat COVID-19, repositioning old drugs for use as antiviral therapy is an interesting strategy because information on safety profile, side effects, posology, and drug interactions is well known (40).

\section{Discussion}

For COVID-19, which started in December 2019 and spread all over the world, scientists have made great progress in the characterization of the virus, and vaccine-drug research that can actively be effective in combating COVID-19 has also accelerated. There is currently no proven antiviral specific for COVID-19. Other drugs recommended for treatment are arbidol (an antiviral drug available in Russia and China), intravenous immunoglobulin, interferons, and plasma of patients recovered from COVID-19 (37-39). Among the candidate drugs to treat COVID-19, repositioning old drugs for use as antiviral therapy is an interesting strategy because information on safety profile, side effects, posology, and drug interactions is well known (40). This indicates that although a pandemic is present, it is necessary to continue the work against the same pandemic with increasing difficulties. At present, more data are needed 
to further demonstrate the effectiveness of antiviral treatments against the virus. In addition, studies are needed to investigate the transmission and pathogenicity mechanisms that need to be revealed. The most important issue is to reveal the molecular mechanism of viral entry and viral replication for targeted vaccine-drug studies.

Peer-review: Externally peer-reviewed.

\section{Authorship Contributions}

Concept: M.G., Design: E.M.G., Data Collection or Processing: M.G., E.M.G., Analysis or Interpretation: M.G., E.M.G., Literature Search: M.G., E.M.G., Writing: M.G., E.M.G

Conflict of Interest: No conflict of interest was declared by the authors.

Financial Disclosure: The authors declared that this study received no financial support.

\section{References}

1. Center JHCR. COVID-19 Map 2020. Available from: https:// coronavirus.jhu.edu/map.html.

2. T.C. Sağlık Bakanlığı. T.C Sağlık Bakanlığı Korona Tablosu 2020. Available from: https://covid19.saglik.gov.tr/

3. Wang Z, Chen X, Lu Y, Chen F, Zhang W. Clinical characteristics and therapeutic procedure for four cases with 2019 novel coronavirus pneumonia receiving combined Chinese and Western medicine treatment. Biosci Trends 2020;14:64-8.

4. Zumla A, Chan JF, Azhar EI, Hui DS, Yuen K-Y. Coronavirusesdrug discovery and therapeutic options. Nature reviews Drug Discov 2016;15:327.

5. Sanders JM, Monogue ML, Jodlowski TZ, Cutrell JB. Pharmacologic treatments for coronavirus disease 2019 (COVID-19): a Review. JAMA 2020;323:1824-36.

6. T.C. Sağlık Bakanlığı. COVID-19 Erişkin Hasta Tedavisi. 2020. Available from: https://covid19.saglik.gov.tr/TR-66926/eriskinhasta-tedavisi.html p. 1-19.

7. T.C. Sağlık Bakanlığı. COVID-19. Çocuk Hasta Yönetimi ve Tedavisi. Available from: https://covid19.saglik.gov.tr/Eklenti/38596/0/covid19rehbericocukhastayonetimivetedavipdf.pdf 2020. p. 1-5.

8. Savarino A, Di Trani L, Donatelli I, Cauda R, Cassone A. New insights into the antiviral effects of chloroquine. Lancet Infect Dis 2006;6:67-9.

9. Aguiar AC, Murce E, Cortopassi WA, Pimentel AS, Almeida MM, Barros DC, et al. Chloroquine analogs as antimalarial candidates with potent in vitro and in vivo activity. Int J Parasitol Drugs Drug Resist 2018;8:459-64.

10. Zhou D, Dai S-M, Tong Q. COVID-19: a recommendation to examine the effect of hydroxychloroquine in preventing infection and progression. J Antimicrob Chemother 2020;75:1667-70.

11. Vincent MJ, Bergeron E, Benjannet S, Erickson BR, Rollin PE, Ksiazek TG, et al. Chloroquine is a potent inhibitor of SARS coronavirus infection and spread. J Virol 2005;2:69.
12. Boelaert JR, Piette J, Sperber K. The potential place of chloroquine in the treatment of HIV-1-infected patients. J Clin Virol 2001;20:13740.

13. Wang L. Cell Res. the press; 2019.

14. Savarino A, Boelaert JR, Cassone A, Majori G, Cauda R. Effects of chloroquine on viral infections: an old drug against today's diseases. Lancet Infect Dis 2003;3:722-7.

15. ClinicalTrials.gov is a database of privately and publicly funded clinical studies conducted around the world. Avaialble from: ClinicalTrials.gov. Home 2020.

16. Devaux CA, Rolain J-M, Colson P, Raoult D. New insights on the antiviral effects of chloroquine against coronavirus: what to expect for COVID-19? Int J Antimicrob Agents 2020:105938.

17. Harrison C. Coronavirus puts drug repurposing on the fast track. Nat Biotechnol 2020;38:379-81.

18. Su B, Wang Y, Zhou R, Jiang T, Zhang H, Li Z, et al. Efficacy and tolerability of lopinavir/ritonavir-and efavirenz-based initial antiretroviral therapy in HIV-1-infected patients in a tertiary care hospital in Beijing, China. Front Pharmacol 2019;10:1472.

19. Cvetkovic RS, Goa KL. Lopinavir/ritonavir. Drugs 2003;63:769802.

20. Chu C, Cheng V, Hung I, Wong M, Chan K, Chan K, et al. Role of lopinavir/ritonavir in the treatment of SARS: initial virological and clinical findings. Thorax 2004;59:252-6.

21. Arabi YM, Alothman A, Balkhy HH, Al-Dawood A, AlJohani S, Al Harbi S, et al. Treatment of Middle East Respiratory Syndrome with a combination of lopinavir-ritonavir and interferon- $\beta 1 \mathrm{~b}$ (MIRACLE trial): study protocol for a randomized controlled trial. Trials 2018;19:81.

22. Cao B, Wang Y, Wen D, Liu W, Wang J, Fan G, et al. A trial of lopinavir-ritonavir in adults hospitalized with severe Covid-19. N Eng J Med 2020;382:1787-99.

23. Lim J, Jeon S, Shin H-Y, Kim MJ, Seong YM, Lee WJ, et al. Case of the index patient who caused tertiary transmission of COVID-19 infection in Korea: the application of lopinavir/ritonavir for the treatment of COVID-19 infected pneumonia monitored by quantitative RT-PCR. J Korean Med Sci 2020;35:e79.

24. Furuta Y, Komeno T, Nakamura T. Favipiravir (T-705), a broad spectrum inhibitor of viral RNA polymerase. Proc Jpn Acad Ser B Phys Biol Sci 2017;93:449-63.

25. Chen C, Huang J, Cheng Z, Wu J, Chen S, Zhang Y, et al. Favipiravir versus Arbidol for COVID-19: a randomized clinical trial. MedRxiv. 2020.

26. Dong L, Hu S, Gao J. Discovering drugs to treat coronavirus disease 2019 (COVID-19). Drug Discover Ther 2020;14:58-60.

27. Bosseboeuf E, Aubry M, Nhan T, Pina J, Rolain J, Raoult D, et al. Azithromycin inhibits the replication of zika virus. J Antivir Antiretrovir 2018;10:6-11.

28. Madrid PB, Panchal RG, Warren TK, Shurtleff AC, Endsley AN, Green CE, et al. Evaluation of Ebola virus inhibitors for drug repurposing. ACS Infect Dis 2015;1:317-26.

29. Bacharier L, Guilbert T, Mauger D, Boehmer S, Beigelman A, Fitzpatrick A, et al. National Heart, Lung, and Blood Institute's 
AsthmaNet. Early administration of azithromycin and prevention of severe lower respiratory tract illnesses in preschool children with a history of such illnesses: a randomized clinical trial. JAMA 2015;314:2034-44.

30. Gautret P, Lagier J-C, Parola P, Meddeb L, Mailhe M, Doudier $\mathrm{B}$, et al. Hydroxychloroquine and azithromycin as a treatment of COVID-19: results of an open-label non-randomized clinical trial. Int J Antimicrobi Agents 2020:105949.

31. ML, DeBolt C, Lindquist S, Lofy KH, Wiesman J, Bruce H, et al. First case of 2019 novel coronavirus in the United States. N Eng J Med 2020;382:929-36.

32. Sheahan TP, Sims AC, Leist SR, Schäfer A, Won J, Brown AJ, et al. Comparative therapeutic efficacy of remdesivir and combination lopinavir, ritonavir, and interferon beta against MERS-CoV. Nat Commun 2020;11:1-14.

33. Arena C. Coronavirus outbreak: Top coronavirus drugs and vaccines in development. Last Accessed Date: 26.03.2020. Available from: https://www.clinicaltrialsarena.com/analysis/coronavirus-mers-covdrugs.

34. Wang D, Hu B, Hu C, Zhu F, Liu X, Zhang J, et al. Clinical characteristics of 138 hospitalized patients with 2019 novel coronavirus-infected pneumonia in Wuhan, China. JAMA 2020;323:1061-9.

35. Türkiye Ulusal Alerji ve Klinik İmmünoloji Derneği. COVID-19 Tedavisinde Kullanılan İlaçlara Gelişen İstenmeyen İlaç Reaksiyonları 2020 Last Accessed Date: 26.03.2020. Avaialable from: https:// www.aid.org.tr/covid-19-tedavisinde-kullanilan-ilaclara-gelisenistenmeyen-ilac-reaksiyonlari/

36. Stockman LJ, Bellamy R, Garner P. SARS: systematic review of treatment effects. PLoS Med 2006;3:e343.

37. Jin Y-H, Cai L, Cheng Z-S, Cheng H, Deng T, Fan Y-P, et al. A rapid advice guideline for the diagnosis and treatment of 2019 novel coronavirus (2019-nCoV) infected pneumonia (standard version). Mil Med Res 2020;7:4.

38. Zhang L, Liu Y. Potential interventions for novel coronavirus in China: a systemic review. Journal of medical virology. 2020.

39. Jie Z, He H, Xi H, Zhi Z. Multicenter Collaboration Group of Department of Science and Technology of Guangdong Province and Health Commission of Guangdong Province for Chloroquine in the Treatment of Novel Coronavirus Pneumonia. Expert Consensus on Chloroquine Phosphate for the Treatment of Novel Coronavirus Pneumonia [in Chinese]. Zhonghua Jie $\mathrm{He} \mathrm{He} \mathrm{Hu} \mathrm{Xi} \mathrm{Za} \mathrm{Zhi}$ 2020;43:185-8.

40. Colson P, Rolain J-M, Lagier J-C, Brouqui P, Raoult D. Chloroquine and hydroxychloroquine as available weapons to fight COVID-19. Int J Antimicrob Agents 2020;105932(10.1016).

41. Golden EB, Cho H-Y, Hofman FM, Louie SG, Schönthal AH, Chen TC. Quinoline-based antimalarial drugs: a novel class of autophagy inhibitors. Neurosurg Focus 2015;38:E12.

42. Agostini ML, Andres EL, Sims AC, Graham RL, Sheahan TP, Lu $\mathrm{X}$, et al. Coronavirus susceptibility to the antiviral remdesivir (GS-
5734 ) is mediated by the viral polymerase and the proofreading exoribonuclease. mBio 2018;9:e00221-18.

43. Tchesnokov EP, Feng JY, Porter DP, Götte M. Mechanism of inhibition of Ebola virus RNA-dependent RNA polymerase by remdesivir. Viruses 2019;11:326.

44. Lo MK, Feldmann F, Gary JM, Jordan R, Bannister R, Cronin J, et al. Remdesivir (GS-5734) protects African green monkeys from Nipah virus challenge. Sci Transl Med 2019;11:eaau9242.

45. Hsieh H-P, Hsu JT-A. Strategies of development of antiviral agents directed against influenza virus replication. Curr Pharm Des 2007;13:3531-42.

46. Hepatitis C guidance 2018 update: AASLD-IDSA recommendations for testing, managing, and treating hepatitis $\mathrm{C}$ virus infection. Clin Infect Dis 2018;67:1477-92.

47. Tsang K, Zhong NS. SARS: pharmacotherapy. Respirology 2003;8:S25-30.

48. Arabi YM, Shalhoub S, Mandourah Y, Al-Hameed F, Al-Omari A, Al Qasim E, et al. Ribavirin and interferon therapy for critically ill patients with middle east respiratory syndrome: a multicenter observational study. Clini Infect Dis 2020;70:1837-44.

49. McQuade B, Blair M. Influenza treatment with oseltamivir outside of labeled recommendations. Am J Health System Pharm 2015;72:1126.

50. Jefferson T, Jones M, Doshi P, Spencer EA, Onakpoya I, Heneghan CJ. Oseltamivir for influenza in adults and children: systematic review of clinical study reports and summary of regulatory comments. BMJ 2014;348:g2545.

51. Shiraki K. Antiviral drugs against alphaherpesvirus. Human Herpesviruses: Springer; 2018:103-22.

52. Guo Y-R, Cao Q-D, Hong Z-S, Tan Y-Y, Chen S-D, Jin H-J, et al. The origin, transmission and clinical therapies on coronavirus disease 2019 (COVID-19) outbreak-an update on the status. Mil Med Res 2020;7:1-10.

53. Furuta Y, Gowen BB, Takahashi K, Shiraki K, Smee DF, Barnard DL. Favipiravir (T-705), a novel viral RNA polymerase inhibitor. Antiviral Res 2013;100:446-54.

54. Goldhill DH, te Velthuis AJ, Fletcher RA, Langat P, Zambon M, Lackenby A, et al. The mechanism of resistance to favipiravir in influenza. Proc Natl Acad Sci U S A 2018;115:11613-8.

55. Cardile AP, Warren TK, Martins KA, Reisler RB, Bavari S. Will there be a cure for Ebola? Ann Rev Pharmacol Toxicol 2017;57:329-48.

56. Rossignol J-F. Nitazoxanide: a first-in-class broad-spectrum antiviral agent. Antiviral Res 2014;110:94-103.

57. Cao J, Forrest JC, Zhang X. A screen of the NIH Clinical Collection small molecule library identifies potential anti-coronavirus drugs. Antiviral Res 2015;114:1-10.

58. Rossignol J-F. Nitazoxanide, a new drug candidate for the treatment of Middle East respiratory syndrome coronavirus. J Infect Public Health 2016;9:227-30. 